\title{
Cash management organisation decision-making: economics, strategy and operations
}

\author{
Wim WESTERMAN ${ }^{1}$ \\ University of Groningen, The Netherlands
}

\begin{abstract}
:
Aim: This article starts from the observations of two experts, who witness varying company views on the almost-vanished issue of structuring the internal decision-making on the organisation of cash management. The aim of this article is to put the current challenging developments in a digitalizing world into a conceptual perspective.
\end{abstract}

Research design: The article singles out motives for either centralization or decentralization of cash management, models to organize cash management functions, as well as developments in the field over the last some thirty years. Various theoretical views are studied briefly in order to find a way out of the signalled paradox into a refined future.

Findings: It can be concluded that multiple practices may coexist both within and between firms, whereby a refined understanding in terms of financial economics, strategic direction and operational flexibility is called for.

Originality: The present study is unique in that it is among the first in academia to signal the return of the centralisation versus decentralisation issue in cash management in a rapidly evolving digital era and a multi-legislation world.

Implications: The developments offer a unique opportunity for firms, further reducing their costs, to overthink their cash management system, including its relation to the external world. The study calls for follow-up research in terms of case studies at organisations with varying contingencies and survey questionnaires among representative samples.

Keywords: cash management organisation, (de-) centralisation, decision-making JEL: B27, G30, L23

${ }^{1}$ The author owes many thanks to the special editors, the reviewers of earlier drafts and the anonymous academic scholars and business people who gave their input to this article.

Correspondence address: Dr. W. Westerman, Faculty of Economics and Business, University of Groningen, Nettelbosje 2, 9747 AE The Netherlands, Email: w.westerman@ rug.nl.

Received: 10.01.2020, Revised: 19.02.2020, Accepted: 13.04.2020

doi: http://dx.doi.org/10.29015/cerem.869 


\section{Introduction}

On November 1, 2017, an interview with Jean-François Caillol was published on the Dutch financial management newsfeed site CM Web. In this interview, he was cited as follows (Geyte 2017). "I expect that the trend towards centralisation in cash management will continue. After all, there will be more and more attention for doing it as efficiently as possible and then I do not believe in decentralisation. After all, a small team can process large amounts of transactions and information. It not only reduces the number of people that need to be deployed, which reduces costs, but it is also more professional." (author's translation)

Jean-François Caillol is not just somebody. He is the long-time treasurer of the giant Belgium-based chemical company Solvay, a forerunner on global cash management since about four decades. Its internal bank handles much of the Group's cash transactions, foreign exchange risk hedging and internal financing and also closely monitors accounts receivable and accounts payable positions in relation to this (Treasury Today 2016). No wonder that his local team was chosen as having the best Belgian practice in treasury in 2016. Moreover, although Caillol notes that technological and regulatory limits (also with Solvay) set a boundary to a full centralisation of activities, the decades-long discussion on this issue seemed to be closed.

However, also in the fall of 2017, the present author had a discussion with a USbased investment banker. He told that his clients had been increasingly taken up the issue of centralisation or decentralisation of cash management, because of the evermore speedy and much diversifying customer requirements in the fast moving industries that he serviced. Discussions with observers learnt that digital technology developments in especially the so-called fintech world and regulatory relaxation on financial services supply fuel a move out of centralisation into decentralisation. If indeed becoming true, this would mean a revolutionary changeover of current preferences. But will it really become like that or do we just witness socio-political challenges nowadays (Riggins 2019)?

The question just posed involves crystal-ball judgement and goes beyond the reach of this conceptual and explorative study. Yet, what will be covered are 


\section{CASH MANAGEMENT ORGANISATION DECISION-MAKING}

motives influencing centralisation and decentralisation of cash management and typical models of zero to full centralisation of decision-making. Following, developments in the field will discussed by looking at states of the art and major issues considered over the last thirty years. A look at the present gives way to various academic views on how to respond to current challenges on organising the cash management decision-making. A brief practical framework and an academic outlook conclude the article.

\section{Centralisation issues}

Cash management ${ }^{2}$ refers to corporate short-term financial management policies (https://wikipedia.org/wiki/cashmanagement). It includes cash flows and transactions management, liquidity management (including investments) and (interest rate, foreign exchange and other) risk management. Cash management decision-making can take place at various levels of companies. If so, centralisation or decentralisation issues may arise on various issues, such as the payment of obligations and collection of receivables, whether and how much to invest in a certain currency, how to handle business with banks and other intermediaries, and so forth. In the remainder of this section, these kind of issues will be discussed.

\subsection{Centralisation motives}

Motives to centralise cash management functions may vary (cf. Westerman, Von Eije 2005; Polák, Klusáček 2010; Treasury Today 2016, Bartsch 2019). First comes the efficiency motive. Administrative costs can be reduced when local affiliate staff time is freed up and bundled at a central level. Also, at this level one may net internal cash flows and pool cash balances, which reduces internal transaction costs and gross interest costs, with synergetic bank deals reducing the costs even further. Moreover, cash balance and cash flow risks and thus expected costs may decline when routing cash bundles centrally via perhaps also less risky

\footnotetext{
${ }^{2}$ Definitions pertaining to cash management are varying. It is preferred to use a simple definition from Wikipedia, which is a source of common knowledge.
} 
financial institutions. Second comes the professionalization motive of centralisation. Data may become more concentrated in better-streamlined information systems, enhancing the cash planning, measurement and evaluation, and enabling cash routing operations including leading and lagging. Also, internal financing benefits are reaped when concentration of financial know-how enables better investment decision-making.

Motives to decentralise cash management are also frequently found in the standard literature (cf. Westerman, Von Eije 2005; Polák, Klusáček 2010; Treasury Today 2016; Bartsch 2019). Firstly, information needs by both the corporation itself and the regulative authorities increases when centralizing. The highly formalised and upgraded information system needed may contradict corporate decentralisation philosophies. Also, affiliate staff may control cash flows more adequately when functions are decentralised. Moreover, decentralised disciplines may have more sight of operational needs. Next, they may possess capacities that corporate staff at headquarters may not have. Finally, established relationships of affiliates with local banks are interrupted when cash balances and flows are managed at the central corporate level. Overall, centralisation of cash management is not obvious, which allows for various organisational models.

\subsection{Centralisation models}

There are several ways to organise cash management functions (Westerman et al. 1997; Polák, Klusáček 2010; Treasury Today 2016). Firstly, cash management may be fully decentralised, with only information being exchanged in the corporation. Secondly, a consultancy model may prevail, in which a central unit advises the affiliates on their short-term financing. Thirdly, an agent model may be employed, with this unit handling cash operations on behalf of the affiliates. With an in-house bank, this unit also provides near-banking services to the affiliates. Lastly, in a shared services model, one or more central units even resume all of the cash management responsibilities of the affiliates.

Not all cash management functions need to be dealt with likewise. Polák and Klusáček (2010) hold that risk management functions and large liquidity positions are centralised first, followed by internal and external cash balances, cash transfers 


\section{CASH MANAGEMENT ORGANISATION DECISION-MAKING}

and the entire liquidity management, and completed by the all cash flow management, debtor and creditor management and a central information system. Blenken Blijdenstein and Westerman (2008) refer to country limits (local regulations, fiscal rules and reporting rules), bank limits (on global banking, ICT issues, cost/return trade-offs) and internal limits (cost-benefit, strategic and control considerations). Caillol (Treasury Today 2016) in addition points out technological challenges and Riggins (2019) signals socio-political uncertainty issues (Brexit, regulatory changes in Asia and rise of protectionist legislation).

\section{Centralisation over time}

Around 1990, the author of this article started with his first cash management projects and studies. In the aftermath of two so-called oil crises resembling pretty much the well-known recent financial crises in terms of economic and social impact, interest rates went up to previously and later unwitnessed post-war levels, whereas the personal computer started a revolution in data processing and analytics. Cash planning and forecasting progress would help to cut costs and increase control. This was often still rather done per local entity, business unit and at best country level than that integrated corporate cash management concepts were employed (cf. Soenen, Aggarwal 1989).

Nevertheless, a broad strive for centralised cash planning and control started at the same time (Westerman et al. 1997). Enthusiastic controllers and treasurers who had been previously building private spreadsheets became assisted by specialised software packages allowing for more rigorous planning and control. Communication via the electronic highway helped to reduce physical and time barriers, but varying accounting practices and local restrictions remained difficult to overcome. Nevertheless, financial markets became deregulated locally, liberalised cross-border and harmonised globally. "Reaganomics", "Thatcherism" and "Europe 1992" movements acted as catalysers here. Head offices were able to take over cash tasks and responsibilities from lower units. A layered bank account structure and a herewith aligned reporting structure were given priority. 
Of course, the trend that started was not general and not always that complete, but seemed almost inevitable (Westerman, Von Eije 2005). Companies like Philips and Solvay saved a lot of money by sweeping bank accounts (pooling) or offsetting payments internally (netting). The banker role became more modest (fee reduction) and detached (disintermediation). Evermore and also smaller firms profited from what became a race to the cost bottom. Banks had to accept margin erosions, but were able to do so because of declining costs on their side in what were abundant times anyway. Cross selling with attractive long-term finance deals also helped to sweeten their pain. When the advent of euro also reduced the exchange costs, things went even better for all.

For over a decade now, the present author is increasingly viewing developments from the side-line, with both much pity and much pleasure though. Indeed, cash management became more efficient in general, with for instance slowly developing accounting system harmonisations and ever closer to real-time cloud applications entering the market. However, limitations of banking systems, practicalities in 'difficult' or 'small' countries, business realignments and limited cooperation from suppliers and customers inhibited the tightening of cash planning and control (Blenken Blijdenstein, Westerman 2008). Moreover, growing insecurity of linked information systems, limited financial crisis resistance of counterparties and regulatory requirements compiled in the course of it, made a complete full centralisation of cash management show to be impossible, even in theory.

As of today in 2020, the new magic words partially match the old ones, but are more eruptive. For example, PSD2 (open banking regulation), fintech start-ups and blockchain technology (the new digital transaction connectors) make the author remind of the disintermediation wave of 30 years ago. Take also for example the emergence of the new so-called crypto-coins, local currencies and documentary credits or whatever the financial transaction routes chosen is. They deregulate, liberalise and harmonise currency markets with almost real-time and free of charge payments, thereby fuelling the embarrassed bankers' efforts in this respect as well. Moreover, since customer relationship management (CRM) and supply chain financing (SCF) require and enable tailor-made solutions, one-fits-all traditional solutions are not that acceptable anymore. 


\section{CASH MANAGEMENT ORGANISATION DECISION-MAKING}

Table 1 below summarises the above, using as yardsticks the years 1990, 2005 and 2020 (Westerman 2017). With this at hand and having arrived in the present, several questions remain and ask for a reply. Can companies handle their business in turbulent cash times? How do they respond to them? Do they want to arrange and control all of the just listed issues? These are questions that may cause headaches to the central cash manager of today, and even more to tomorrow's. The question whether he or she should focus on everything around cash and wants to deal with it becomes topical again, since much can also be done more easily and perhaps more appropriately at affiliate levels. Of course, to set rules and keep an overview is a good thing, but looser reins may let the cash horses run faster, so to say.

\section{Table 1. Cash management developments}

\begin{tabular}{|c|l|l|}
\hline Year & $\begin{array}{l}\text { On centralising cash } \\
\text { management }\end{array}$ & $\begin{array}{l}\text { Key themes around cash management } \\
\text { centralisation }\end{array}$ \\
\hline 1990 & "It should become true soon" & $\begin{array}{l}\text { Reporting, planning \& control, account } \\
\text { structure }\end{array}$ \\
\hline 2005 & $\begin{array}{l}\text { "We don't get much } \\
\text { further" }\end{array}$ & $\begin{array}{l}\text { Efficiency, payment systems, security, } \\
\text { supervision }\end{array}$ \\
\hline 2020 & "Towards a refined future" & $\begin{array}{l}\text { Digitalisation, suppliers, customers, } \\
\text { uncertainty }\end{array}$ \\
\hline
\end{tabular}

Source: adapted from Westerman (2017).

\section{Centralisation views}

Whether centralising or not: the increased complexity of the cash management function makes it necessary to review it in detail. Polák, Masquelier and Michalski (2018) point at four drivers in this respect: contextual challenges, technology/IT systems, new tasks and required skills. They also note an evolution towards less operational staff tasks, more analysis and reporting, and much more strategic tasks. Standardisation and simplification will enable digitisation of processes, but the authors question centralisation of processes in a global context. The trend towards application of artificial intelligence (Polák et al. 2019) in the field makes a process 
approach even more pithy. When accepting that centralisation is returning as an issue anyway, the cash management function thus has to take a step beyond the one just described. However, also various other views are at hand.

Firstly, cost-benefit and net present value analyses may be helpful (Westerman, Ritsema 1999). Cost savings and profit margins may offer a yardstick in concrete one-off and limited timeframe issues. In the latter case, measures such as break-even analyses and payback periods may also be helpful. Yet, with an extended timeframe, net present value (NPV) analyses may be better. They allow for economic cash flows instead of accounting profits and discount net receivings back to the present. Nevertheless, a correct NPV determination may be a tricky exercise, if thinking of unquantifiable or unsure cash flow probabilities, as well as disputable interest and equity cost charges. Also, the length of the applicable forecast period may be debatable. Then it may be wise to refer to results and/or to take a broader view.

Transaction cost economics (TCE) is developed by Williamson (1975; 1989). This theory views governance structure issues with transactions. It takes on board not just (direct) production costs, but also coordination and motivation costs. The asset specificity of the transactions, as determined by e.g. frequency and size, is of crucial importance here. Depending on this, the optimal level of centralisation may be determined per cash management task. Since both quantifiable and unquantifiable costs are allowed for, the perspective becomes eclectic. It also becomes dynamic, since variations in costs over time are implied. Yet, the TCE opportunism view is essentially a static strategic approach, with long-term (inter-) organisational relationships being overlooked.

However, in cash management, reciprocal alignment processes often matter, creating long-term bonding. Other than TCE, the network theory allows for this, by including notions such as trust, mutual adaptation and learning (Hallèn 1982; Nooteboom 1993; see also Bartsch 2019). Cash management centralisation is judged from the perspective of staff performing their tasks in multiple relational settings. Going beyond the above, cultural affinity may play a role as well, as do various legislative frameworks and business ethics considerations (Bartsch 2019). Lastly, professional judgement, or call it less sophistically: personal preferences, may 


\section{CASH MANAGEMENT ORGANISATION DECISION-MAKING}

matter as well. Refer for a comprehensive elaboration on cash management organisation views to Table 2 below.

\section{Table 2. Cash management organisation views}

\begin{tabular}{|l|l|l|}
\hline \multicolumn{1}{|c|}{ Focus } & \multicolumn{1}{|c|}{ Name/label } & How to (de-) centralise cash management \\
\hline Process & Task analysis & Digitise if possible, centralise when fitting \\
\hline Accounting & Cost-benefit analysis & Centralise if profitable, else decentralise \\
\hline Economics & $\begin{array}{l}\text { Net present value } \\
\text { analysis }\end{array}$ & Centralise if value creating, else decentralise \\
\hline Governance & $\begin{array}{l}\text { Transaction cost } \\
\text { economics }\end{array}$ & Centralise if asset specificity does allow for it \\
\hline Relationships & Network analysis & Value network determines (de-) centralisation \\
\hline Context & $\begin{array}{l}\text { (rather directive } \\
\text { factors) }\end{array}$ & $\begin{array}{l}\text { Culture/legislation/ethics/judgement shape } \\
\text { view }\end{array}$ \\
\hline
\end{tabular}

Source: author's own elaboration.

As a refinement of the above, the various parts of cash management can be split up and viewed separately. Traditionally, a division between third party accounts receivable, third party accounts payable, inter-company transfers and liquidity management is made, with the latter two parts being the most centralised ones and especially third party accounts receivable being the least centralised one. In doing so, various grade of centralisation scenarios may be witnessed (Blenken Blijdenstein, Westerman 2008). The focus of the scenario's may range from truly global, via restricted global, towards internally oriented and finally truly local. It is needless to say that general scenarios may in practice demand for slightly different practices, depending upon local peculiarities.

\section{Conclusion}

Whereas technological, legislative and organisational developments historically have led to increased centralisation of the decision-making on cash management activities, this seemingly ongoing trend may have halted because of legislative and organisational hamperings and in the evolving digital era and multi-legislation world 
even reversal decentralisations are deliberated. This creates a unique opportunity for firms, further reducing their costs, to overthink their cash management system, including its relation to the external world. A solution to today's challenges is perhaps not a 'one fits all and forever' centralisation of decision-making, but a refined understanding in terms of financial economics, strategic direction and operational flexibility (see Table 3 below).

\section{Table 3. Cash management organisation framework}

\begin{tabular}{|l|l|l|}
\hline \multicolumn{1}{|c|}{ Financial economics } & \multicolumn{1}{|c|}{ Strategic direction } & Operational flexibility \\
\hline $\begin{array}{l}\text { Financials: NPV, } \\
\text { payback, } \\
\text { profit/margin/cost, } \\
\text { hunches }\end{array}$ & $\begin{array}{l}\text { Transactions: tasking, size, } \\
\text { frequency, opportunism/trust, } \\
\text { culture, ethics }\end{array}$ & $\begin{array}{l}\text { Externalities: government, } \\
\text { sup-pliers/customers, } \\
\text { banks/fintech }\end{array}$ \\
\hline
\end{tabular}

Source: author's own elaboration.

The transaction perspective stands in the middle here. In line with McMenemy (2019), cash transactions should all be registered, tracked and reported on, as well as planned for and controlled, as direct as possible to the strategic activities that they are related to. A concomitant decentralisation of the decision-making would also offer a high flexibility in both the intra- and intercompany world. In practice, capacities and heuristics would impose limits to this base guideline, however. Moreover, financial economics considerations might call for bundling of groups of tasks as one anyway. Thus, acceptance of shortcomings as well as sound professional judgement are both still being asked for.

Overall, being almost gone with the wind of time, cash management organisation decision-making in organisations is coming back as an issue. A contribution of this article is that it is among the first to signal the possible impact of recent developments in this respect. In addition, taking into account historical developments and organisational structure models, it shows how theoretical views may help to study actual (de-) centralisation issues. Yet, the article does not go beyond initial stages of the research cycle. Future researchers are encouraged to study how organisations act upon the current challenges. Case studies at 


\section{CASH MANAGEMENT ORGANISATION DECISION-MAKING}

organisations with varying contingencies, as well as survey questionnaires among representative samples, may shed more light on what is and may be done.

\section{References}

Bartsch C. (2019), Factors to consider when centralising cash management, The Global Treasurer, 10 September, https://www.theglobaltreasurer.com/2019/09/10/factors-to-consider-when-centralisingcash-management/ [24.04.2020].

Blenken Blijdenstein H., Westerman W. (2008), Optimising a global cash management structure at Philips Electronics, "Journal of Corporate Treasury Management”, vol. 1 no. 4, pp. 317-325.

Geyte J. (2017), Interne bank als dienstverlener, geen winstmotor, CM Web, 1 November, https://cmweb.nl/2017/11/interne-bank-als-dienstverlener-geen-winstmotor/ [25.04.2020].

Hallèn L. (1982), International industrial purchasing, University of Uppsala, Uppsala.

McMenemy L. (2019), The role of the head of treasury in entity governance, 19 July, https://insights.diligent.com/entity-governance/role-head-treasury-entity-governance/ [25.04.2020].

Nooteboom B. (1993), Networks and transactions: do they connect?, in: Dynamics of the firm. Strategies of pricing and organisation, Groenewegen J. (ed.), Edward Elgar, Aldershot, pp. 9-26.

Polák P., Klusáček I. (2010), Centralisation of treasury management, Business Perspectives, Sumy (Ukraine).

Polák P., Masquelier F, Michalski G. (2018), Towards treasury 4.0. The evolving role of corporate treasury management for 2020, "Management - Journal of Contemporary Management Issues", vol. 23 no. 2, pp. 189-197.

Polák P., Nelischer C., Guo H., Robertson D.C. (2019), "Intelligent” finance and treasury management: what we can expect, “AI \& Society", vol. 2019, pp. 1-12.

Riggins N. (2019), Centralisation versus decentralisation, “The Global Treasurer”, 8 February.

Soenen L.A., Aggarwal R. (1989), Cash and foreign exchange management. Theory and corporate practice in three countries, "Journal of Business Finance \& Accounting", vol. 16 no. 5, pp. 599-616.

Treasury Today (2016), Taking a flexible approach to centralisation, http://treasurytoday.com/2016/09/taking-a-flexible-approach-to-centralisation-ttii [25.04.2020].

Westerman W. (2017), Ja toch weer! Cash management: centralisatie of decentralisatie?, CM Web, 12 December, http://cmweb.n1/2017/12/cash-management-centralisatie-decentralisatie/ [25.04.2020].

Westerman W., Von Eije J.H. (2005), Multinational cash management in Europe towards centralisation and disintermediation: the Philips case, "Managerial Finance", vol. 31 no. 10, pp. 65-74. 
Westerman W., Hessels J., Ritsema H.A. (1997), Treasury management in a Euro-Japanese firm, in: Proceedings 8ste NOBO Onderzoekdag Bedrijfskunde, 18 november, University of Twente, Enschede, pp. 105-115.

Westerman W., Ritsema H.A. (1999), Cash management in a changing European market, in: Financiering en Belegging 1999, Annaert J., Huisman R., Spronk J. (eds.), Erasmus University Rotterdam, Rotterdam, pp. 263-291.

Williamson O.E. (1975), Markets and hierarchies. Analysis and antitrust implications, Free Press, New York.

Williamson O.E. (1989), Transaction cost economics, in: Handbook of industrial organization, part 1, Schmalensee R., Willig R. (eds.), North Holland/Elsevier, Amsterdam, pp. 135-178. 